\title{
Reclaiming Luce Irigaray: Language and Space of the "Other"
}

\author{
Zhang Pinggong \\ The Faculty of English Language and Culture, Guangdong University of Foreign Studies, Guangzhou, China
}

Copyright $\mathrm{C} 2018$ by authors, all rights reserved. Authors agree that this article remains permanently open access under the terms of the Creative Commons Attribution License 4.0 International License

\begin{abstract}
French feminist Luce Irigaray takes up some essential conceptions of post-structuralist thinkers as a start-point, and advances arguments on the logical oppositions based on male and female dichotomy. According to Irigaray, this dichotomy is explicitly related to language. In order to subvert discursive hegemony of patriarchy, it is imperative for women to invent and utilize a language strikingly different from that of the male. This innovative language, also known as "parler femme" or space of the "other", can be employed to construct women's subjectivity. Irigaray prioritizes language over social conscious and ideologies, considering physical and spiritual difference between women and men as instrumental for women's sovereignty and identity. And women's subjectivity can only be constructed on gender difference. Through a language by women, of women and for women, their subjectivity, intellectual enlightenment, cultural conscious, individual improvement, sexual harmony allowing diversity as well as gender equality can reasonably be materialized.
\end{abstract}

Keywords Luce Irigaray, Feminism, Language, Difference, Subjectivity

\section{Association and Influences}

In Ce sexe qui n'en est pas un (This sex which is not one) and other works, Irigaray focuses on the absence of women from the social order and explores analogies between sexuality and language. Irigaray finds out that, throughout the entire Western cultural tradition, women have been assigned no place in history. Alternatively, women have been put in the schizoid position of being simultaneously in history and not in history -- "written out" of history by male power. They appear as exterior representations of various kinds or as objects of men's desire. Therefore, Western tradition is shaped by masculinity. Women's rights are not represented and the feminine is suppressed. For Irigaray, however, there are connections between women's bodies and women's meaning-making in language. She argues that this difference is shaped by the female body and rests in women's capacity for decentred, multiple sexuality and women's language. She contends that women's identity can be autonomous and explorable only within a radically separatist women's movement. Some essential concepts of feminist theory advanced by Lucy Irigaray will shed light on the understanding and criticism of own feminist theory and, more generally, of the French school of thought on gender politics. Focusing on Irigaray's tenets about sexuality and language, the author of this essay attempts to discuss the essential themes of this "French side of the divide", indicating that although the theories of the French group are characteristically radical in their own right, they are in many ways instrumentally problematic in political and social applications.

Essentially, French feminists, such as Kristeva, Irigaray and Cixous are concerned with language and psychology. They take as their start-point the insights of major post-structuralists, especially Lacan, Foucault and Derrida in their treatment of subjectivity and femininity. For these feminist theorists, the claim of sexual difference is the site of a different kind of feminine voice. This special voice is variously described by Lucy Irigaray as parler femme ("woman speaking"), by Helene Cixous as ecriture feminine ("feminist writing"), and by Julia Kristeva as the semiotic.

None of these women philosophers fully accepts the distinction between "man" and "woman"; further, they question the binary logic which supports the male/female duality. However, for the reason that this binary logic is most clearly related to language, it can only be subverted by a different sort of language. This different, revolutionary language is for each of these thinkers a female or woman-identified language: a language celebrating women's identity.

There are two major sources of influence on this school of French feminist criticism, namely, Derrida's deconstruction and Lacan's deconstructive approach to the theory of psychoanalysis by Freud. As indicated by Brook, "Debates in the area of feminism, sexuality and textuality 
have been explored and 'dramatized' in the work of the French feminist deconstructivists-Irigaray, Kristeva and Cixous - in their dialogue with the work of Derrida and Lacan." (1997:69) [1]

The term deconstruction is virtually synonymous with the work of Jacques Derrida, who has used it to characterize the kind of critical effort that he advocates. Derrida's most immediate point of reference was the notion of structure. It involves the dismantling into their constituent features of all types of unities, systems, theories, etc. Thus, if structuralism aims to "construct" the system of logical relations governing the disposition of individual elements in a text, deconstruction is, among other things, a critique of structuralism, which is seen as simply one more stage in the process of metaphysics. Derrida argues that metaphysical systems are "centered" structures that depend on a paradoxical logic according to which the centre is understood as both present in, and independent of, the structure. In this form, the relationship between centre and structure appears as a hierarchical opposition in which one term is understood to embody truth and the other is seen as merely a negative copy: norm/deviation, sane $/ \mathrm{mad}$, mine/yours, authority/obedience (Eagleton, 1996) [2], or as an especially important case for Derrida, speech/writing. This last opposition displays the curious logic of the supplement, which, when teased out by a deconstructive reading, can be seen to subvert the process by which a piece of writing is said to produce meaning. Instead of appearing as a mere representation of the truth that is present in speech, writing is thus shown as what, according to Derrida, a field of limitless play is like, which is characterized by the movement of differance, a word invented by Derrida combining "difference and deferral" (Storey, 1997:94) [3].

Constructionists argue that linguistic meaning is "constructed" through contrasts between binary opposites such as black/white, and that the choice of one of these terms as positive (usually white) depends on the negation or oppression of the opposite term (usually black). Deconstruction pulls apart (deconstructs) the process which creates and naturalizes these oppositions, deconstructing, for example, the ways in which women are associated with nature (inferior) and men with culture (superior).

\section{Language and Differences}

French feminists are determined to replace this ideology with alternative women's language, parle femme or ecriture feminine. The writings of Lucy Irigaray, in particular, contain new forms of expression, using attributes of female sexuality (of jouissance and multiple pleasure) to replace phallocentric (male) pleasure which is singular (the Phallus). Irigaray's account emphasizes the multiple or plural styles of female sexuality and expression, which can also be interpreted ambiguously in terms of her own claim of female sex being not one (Irigaray, 1981)[4]. Her persuasive description of the figure of the sexual lips that are constantly "in touch" with special sensuality of the female body is both symbolic and tactical. It aims at producing difference that can be attributed to women the right to voicing themselves differently. Irigaray is not mystifying the nature of language. What she debates about is creation of women's language. In Irigaray's words, what women want is a language of their own, a currency of exchange or a "non-market of economy". For her, this language can only emerge from women's sexual difference. As she remarks,

"Female sexuality has always been conceptualized on the basis of masculine parameters. Thus the opposition between 'masculine' clitoral activity and 'feminine' vaginal passivity, an opposition alternative which Freud - and many others - saw as stages, or alternatives, in the development of a sexually 'normal' woman, seems rather too clearly required by the practice of male sexuality" (1981:99)[5].

Jacques Lacan's theory of psychoanalysis also influences French feminism immensely. Lacan creatively updated and reworked the principal conceptions by Freud, with the understanding that it is through an attendance to language and linguistic structures (as theorized via Saussure and Jakobson) that the structures of the unconscious are to be understood. His most famous pronouncement is "The unconscious is structured as a language" (Barry, 1995:111)[6]. According to Lacan, the patriarchal system comes in at the Symbolic stage and it silences women. They are excluded and outcast as "the others". They are deprived of language because they cannot escape from the Imaginary into the Symbolic order, as males can or, strictly, they can enter the Symbolic but only by being what they are not, which is a way of masquerade.

Irigaray thus contests Lacan's idea that the Unconscious is structured like a language and that it is the discourse of the Other. More precisely, she argues that if the Unconscious is structured like a language, it is not the language that Lacan imagines. Irigaray argues that language is not a system of pure signifiers, but is always made up of heterogeneous elements: semiotic drive force and symbols. The other, then, is not a pure signifier. It too is made up of these heterogeneous elements. The Other, or the system of language into which we are born, is not the metonymical space that Lacan imagines, in which one signifier is associated with, or displaces, another. Rather, for Irigaray, the Other is the space of subjectivity and human life-preceding Lacan's mirror stage. Whereas Lacan sees the mirror stage as the onset of the subject through its entry into the world of the signifier, Irigaray hears the murmurs of subjectivity before the mirror stage in 
a subterranean world out of which the signifier develops.

Paradoxically, Lacan's marginalization of women has given a boost to post-modern feminist theory. Interpretation of structuralism informs that the meaning is not an independent representation of the real world understood by an already constituted subject, but part of a system that produces meaning, the world and the possibility of a subject. If identity is a construction and not an absolute fixed reality, then this opens up immense scope for feminist thinking. In light of this, Lacan's ideas of the self as fictitious can be seen as weapons for French feminism.

Therefore, different from Freud's or Lacan's theories of sexuality particularly, which define women as negatively imaginary, incomplete, an empty signifier (the vacant womb), French feminists, Irigaray in particular, view feminine sexuality as either subordinate to the needs and desires of men (imagined sexuality by men) or autonomous and explorable only within a radically separatist women's discourse (a schizoid duality). The reason for this positioning, according to Irigaray, is that women have been put in the schizoid position of being simultaneously in history and not in history - "written out" of history by male theory.

Irigaray's style of writing is experimentally feminine, "sexism in language" (Humm, 1995:258) [7]. She articulates.

"Not to mention her language in which 'she' sets off in all directions leaving 'him' unable to discern the coherence of any meaning. Hers are contradictory words, somewhat mad from the standpoint of reason, inaudible for whoever listens to them with ready-made grids, with a fully elaborated code in hand. For in what she says, too, at least when she dares, woman is constantly touching herself. She steps ever so slightly aside from herself with a murmur, an exclamation, a whisper, a sentence left unfinished... When she returns, it is to set off again from elsewhere. From another point of pleasure or of pain, one would have to listen with another ear, as if hearing an 'other meaning' always in the process of weaving itself, of embracing itself with words, but also of getting rid of words in order not to become fixed, congealed in them." (1981:103)[8]

In order to bring the body, replete with drives, back into structuralism, Irigaray employs two very different strategies. First, she brings the speaking body back to signification by maintaining that bodily drives make their way into language. The notion of the semiotic element in language is developed in order to bring the body back into the structure of language. Bodily drives make their way into language through the disruptive but necessary force of this semiotic element. Then, the consequences are:
"The relatively secure meanings of 'ordinary' language are harassed and disrupted by this flow of signification, which presses the linguistic sign to its extreme limit, values its tonal, rhythmic and material properties, and sets up a play of unconscious drives in the text which threatens to split apart received social meanings" (Eagleton, 1996:163)[9].

Like Cixous's ecriture feminine, the language of Irigaray's parle femme can be regarded as the explanation of "female physiology", something worth celebrating for women in their own right.

For Irigaray and Kristeva, symbolic language makes claims about reality, affirms by positing what is, and asserts truths about the natural, social, and cultural worlds in which we live. By contrast, the semiotic provides an alternative to the male affirmative postulates of the Symbolic. The semiotic is not only described as a special receptacle, but also the origin of the idea of the chorus - a field of nondeterminate flow and flux. Here semiotic elements are given their fullest sense of activity and motility. The semiotic is the space of emotion, feeling, drives, waves of energy, bodily rhythms, and poetic language. This style of language can be defined as women's body language or feminist vocabulary which can further be defined as different semantic usages. Technically, Irigaray tries to dismantle phallocentric language by adapting the strategy of mimetism, grammatical alteration and a method of "excess". Burke said that "Like Derrida, Irigaray underscores the functions of spaces, pauses, and the white of the page in the act of reading by stressing their roles as 'figures' in signifying practice" (1994:255)[10].

The commonality of the language style is double fold. One is in the graphic, ranging from rhythm to syntax. The other is in what "they come together" on the question of style - the manner of "deconstructive encounter of texts" (Whitford, 1994:83)[11], as can be demonstrated in most Irigaray's works.

The user of such language is seen as a kind of freedom-fighter in the communicative environment. As this style of writing is "transgressive, rule-transcending and intoxicated" (Barry, 1995:128)[12], it is hard to be theorized in a conventional way. This stylistic weirdness is sometimes compared to e. e. cummings or James Joyce, namely, avant-garde or experimental style characteristic of distortion and free manipulation of linguistic devices $(\mathrm{Hu}$, 1997)[13]. However, in view of Irigaray, this language derives from women's sexual difference. This language difference, according to modern linguistics, is classified as one of "semantic usage in women's genderlects" (Humm, 1995:144). As Silverman remarked,

"Symbolic language makes claims about reality, affirms by positing what is, and asserts truths about 
the natural, social, and cultural worlds in which we live. By contrast, the semiotic provides an alternative to the male affirmative postulates of the symbolic. The semiotic is described as a chora - the Platonic receptacle, but also the origin of the idea of the chorus - a field of nondeterminate flow and flux. Here semiosis is given its fullest sense of activity and motility. The semiotic is the space of emotion, feeling, drives, waves of energy, bodily rhythms, poetic language." (1998

[:B4]

Irigaray's "erudite background" suggests that although she is working primarily in philosophy, she is also a psychoanalyst and linguist at the same time (Whitford, 1990:106)[15]. The reason that she was expelled from Lacanian "school" is because of her outspoken critiques. Like Cixous, Irigaray advocates the possibility of feminist writing which has always been radical and controversial. Feminist writing is probably the first theory to rewrite most forcefully the basic concepts and realities from the standpoint of women. It thus has revolutionary significance. Writing and language of the body seemly enable women to enter history (Zhang, 1998; Zhang, 2001) [16][17]. As a "counterattack" to the discourse of patriarchy, they believe that exploration of women language generates social change. Through this writing of women, by women and for women, the creation of concepts of woman culture and the establishment of new social institutions are probable.

Irigaray's feminism looks at the fundamental interests of men and women as essentially divergent. Concretely, the patriarchal oppression, the marginalization by dominant male power, the control and repression of women by men are the striking forms of social division and historical develoment. The French feminists, Irigaray, in particular, try to find out the route and strategy to win back the benefits and rights of women. In a way, Irigaray has stressed that the probable way out is to follow a new direction of female separatism. Theoretically, she has advanced that in late capitalism it has become possible for women to launch a radical transformation of gender relations in order that a more fair and healthy society can be envisaged and eventually materialized. In Irigaray's words, "To re-establish elementary social justices, to save the earth from total subjugation to male values (which often give priority to violence, power, money), we must restore this missing pillar of our culture." (1994:112)[18]

Nevertheless, feminist writing theorized by Irigaray as a source of political inspiration is arguably regarded as a Utopian experimentation. Consequently, it has some limitations. According to Toril Moi, writing can only be used as medium for liberation, but not as instrument. As a signifying practice, the function of language is limited in its functional endeavors to change social reality. Thus feminist writing lacks acting power (Zhang, 1998)[19]. Writing of the body is not the same as social pragmatic discourse because the former is a "textual strategy of essentialism" (Braidotti, 1994:124)[20], a strategy based on the belief that essential differences between females and males are crucial for women's subjectivity, while the latter is a place where power and politics meet. Isolating sexuality from the societal only results in inefficiency in practical reform. Writing the body does not bring forth mass emancipation of women for the reason that this writing is but psychological experimentation, "thought work", in other words. The poetic and radical style of feminist theory is therefore powerless in dealing with political and social issues for women. Focusing on biological gender difference, Irigaray's theory is thought to be conservative in nature. Her over-emphasis on the specificity of woman's body boarders on separatism and physiological fatalism, thus cause further uncertainties and problems.

Irigaray gives language predominance over social and political issues. As a matter of fact, differences of sexes are "the rhetoric of difference" (Humm, 1995:39)[21] that women come to realize from their bodies. Differences of body are dwarfed when compared with differences of ethnicities, classes, geographies and nationalities. As matter of fact, Irigaray's attempt to generalize women of different essence regardless of their situational differences bares the characteristic of undesirable universalism.

Influenced by predecessor thinkers, Irigaray creates a fantastical philosophical genealogy or "feminist counter-genealogies" (Braidotti, 1994:121)[22]. With obviously radical Nietzschean style, "Her texts create a symbolic position for women in culture and elaborate sexual difference as the major philosophical issue of our age" (Martin, 1999:247)[23]. She advocates that by establishing the subjectivity of women through representation and experience, they can find their place in human civilization and history.

Looking back in history, it is normally admitted that the record of the achievement of men and the civilizations they have built indicates that much of the world has been patriarchal. In historical accounts, very little is recorded about the thoughts, feelings and achievements of women. Indeed, women have been regarded as scarcely better than childbearers. It largely means, in Irigaray's terms, that the possibility of social and cultural life depends upon a "ho (m)mo-sexual monopoly". The law that orders our society is the exclusive valorization of men's needs and desires, of exchanges among men. "What the anthropologist calls the passage from nature to culture thus amounts to the institution of the reign of hom(m)o-sexuality." (1981:171) [24]This is the issue, which, according to Irigaray, "gravitates around the fact that man has defined himself with reference to his own genre, and in so doing believed his divine to be representative of the whole of the genre human" (Martin, 1995:135)[25].

"For woman is traditionally a use-value for man, an exchange value among men; in other words, a commodity. As such, she remains the guardian of material substance, whose price will be established, 
in terms of the standard of their work and of their need/desire, by 'subjects': workers, merchants, consumers. Women are marked phallicly by their fathers, husbands, procurers. And this branding determines their value in sexual commerce. Woman is never anything but the locus of a more or less competitive exchange between two men, including the competition for the possession of mother earth" (Irigaray, 1981: 104)[26].

A statement by a lexicographer makes it even clear:

"Properly speaking, a man is not married to a woman, or married with her; nor are a man and woman married with each other. The woman is married to the man...we do not speak of tying a ship to a boat, but a boat to a ship. And as long as woman generally lives in her husband's house and bears his name - still more should she not bear his name - it is the woman who is married to the man" (Qin, 1996:20)[27].

Etymologically, the Latin word "maritare" meaning "to marry" or "married" is neutral with no preference in either males or females. For the reason that this viewpoint of a Richard White is also mistakenly shared by other lexicographers, such as Noah Webster (1828), Walter W. Skeat (1918) and Ernest Weekley (1921), the prejudiced concept of matrimony remains to date (Ibid).

Irigaray interrogates,

"The society we know, our own culture, is based upon the exchange of women. Without the exchange of women, we are told, we would fall back into the anarchy (?) of the natural world, the randomness (?) of the animal kingdom. The passage into the social order, into the symbolic order, into order as such, is assured by the fact that men, or the groups of men, circulate women among themselves, according to a rule known as the incest taboo."(1985:171)[28]

Against historical background of hegemonic patriarchy, Irigaray firmly believes that the mother-daughter relationship is vitally important. She regards this relationship as one of divinity. The significance of the relationship lies in its potential of establishing female as subject (Martin, 1994:248)[29]. In the process, the earlier traditional analysis of "mother" and natural function of "mother" is challenged and the double bind of the maternal issue is stressed. Therefore, motherhood becomes a weapon powerful both in the context of patriarchal domination of women and for the strongholds of female identity. Luisa Muraro thus comments, "According to Irigaray, the genealogical link serves to symbolize what takes place between mother and daughter, allowing us to overcome the patriarchal regime of lack of differentiation and rivalry between women" (1994:324) [30].
"Women must love one another both as mothers, with a maternal love, and as daughters, with a filial love. Both of them. In a female whole that, furthermore, is not closed off. Constituting, perhaps, both of them in one female whole that is not closed up, the sign of infinity? Achieving through their relations with each other, a path into infinity that is always open, in-finite." (Irigaray, 1993:105)[31]

The theme of divinity is a crucial aspect of Irigaray's mimetic strategy for the possibilities of "women-becoming-subjects". For the male, the subjectivity is ensured by the Father-God. For the female, she "has no God, no divine, and no goal. Without a God, what becomes of her will? To the extent that it can be said to be hers at all, it is a kind of amorphous meandering at best a passive nihilism." (Martin, 1994:135) [32]

Therefore, a different concept of the divine is necessary for female subjectivity, that is, the divine relationship of the mother-daughter which is believed to realize female subjectivity. This notion of the divine for women prevents the dissembling of the mother-daughter relationship and keeps their self-reliance.

By revealing a concealed masculine bias in tradition and history, French feminist writing criticizes the gender structure of society. Irigaray's framework of genealogy of women is particularly useful in this aspect. In this framework, the relationship among women is subject to subject, rather than a negative copy shadowed by men. Feminist writing, as an anti-rational measure, is functional in bringing plenty of aspiration and strength for women, with which they can create the future at their will.

In "The 'Mechanics' of Fluids", Irigaray elaborates the rhetorical feature of "fluidity". Irigaray suggests that female fluidity is what "leaks out" or "flows" out of the discourse of masculinity. Irigaray pointed out that "Women diffuse themselves according to modalities scarcely compatible with the framework of the ruling symbolics... Otherwise they might even go so far as to disturb that third agency designated as the real $-a$ transgression and confusion of boundaries that it is important to restore to their proper order. (1981:107) [33] Accordingly, the nature of woman's speech is fluid and hysterical as opposed to the straight-forward and rigid characteristics of the phallocentric. She reveals,

"Must this multiplicity of female desire and female language be understood as shards, scattered remnants of a violated sexuality? Sexuality denied? The question has no simple answer. The rejection, the exclusion of a female imaginary certainly puts woman in the position of experiencing herself only fragmentarily, in the little-structured margins of a dominant ideology, as waste, or excess, what is left of a mirror invested by the (masculine) subject to reflect himself, to copy himself." (1981:103)[34] 
According to Margaret Whitford, there have been two important ways of approaching Irigaray. One is that she is seen as a biological essentialist, which suggests that there is an essential feminine difference derived from biological differences. The performing of the difference is thus organically repressed by patriarchy. By "proclaiming a biological-given femininity", the biological can somehow be conducive to establishing femininity. The other is the reading of Irigaray as a "psychic essentialist" within the theoretic framework of Lacan. This reading proposes that due to Irigaray's purposeful misunderstanding and misrepresenting of the major concepts of Lacan's theories, the issue of the feminine is misplaced in the stage of "a pre-given libido, prior to language". Thus specific female drives are found that posit "two distinct libidos - a masculine and a feminine" (Whitford 1990:107)[35]. The highlighting by Whitford on the two approaches is of great importance. It suggests that Irigaray's theory of feminism is not an ordinary project. Rather, it is a discursive break-through in terms of theory and practice in the postmodern times. It is believed that development of feminism today has well entered a new period. The mode of postmodern feminism, in sociological terms, is still "up for grabs" (Spybey, 1996)[36]. For Irigaray, the radical deconstructive approach is only a central theme in her critical account. Her commitment to feminist politics is the advancement of theory of difference, i.e. motivations enabling women to develop "a separatist space" (Brooks, 1997:80)[37].

\section{Critical Appreciation}

A feminist philosopher, Irigaray firmly rejects feminist ambition of equality "as an intelligible goal for women, on the grounds that the conditions for its intelligibility have not yet been met" (Whitford, 1994:380)[38]. The reason, for Irigaray, is that the desire to be equal to men does not mean a shift of binary structure of dominating and dominated, nor to engage desire attached to women. The achievement of equality may bring some necessary, temporary gains, but they will only mean that women are participating in the reproduction mechanisms of patriarchy. As a strategy, Irigaray agrees to women struggling for equal rights (Ibid). In a long run, efforts for equality by women only "contribute to the erasure (effacement) of natural and spiritual reality in an abstract universal which is in service of a single master: death" (Ibid). The issue at stake is that the poor and underdevelopment arising from women's submission by and to a culture that oppresses them makes of them a medium of exchange only, with limitless exploitation. Because women are still living in the situational realities of the "quasi monopolies of masochistic pleasure, the domestic labor force, and reproduction"(Ibid.104).

The essential claims of Irigaray are of the concern that women should be encouraged to be strategic about their undertakings. They need to be tactical in keep themselves independent from men for the benefit of defending their own domains and objectives. In terms of language acquisition, they should try to formulate their own language, and to discover the love of other women while sheltered from men's hegemonic choices that "put them in the position of rival commodities, to forge for themselves a social status that compels recognition, to earn their living in order to escape from the commodities of prostitute." (Irigaray, 1993:105)[39]

For Irigaray, in order for them to obtain a favorable position on the "exchange market" and to avoid their proletarianization, women are in the need of breaking through these indispensable stages. The dilemma will appear: it is by no means desirable that the order of things should be reversed, because in so doing, "history would repeat itself in the long run, would revert to sameness: to phallocratism. It would leave roots neither for women's sexuality, nor for women's imaginary, nor for women's language to take their place" (Ibid).

As previously revealed, in the patriarchal context, no symbolic signification is attributed to the female sex. She is visualized as a "hole" or "lack", opposed, in this binary economy, to the male subject as the other, or object. She has no identity of her own. The symbolic violence of this repression is that she has no language with which to represent herself. It is Irigaray's contention, then, that the feminine must be represented in the Symbolic to achieve identity and to be valued in culture. Engaging the Heideggarian notion of language as the "house" of subjectivity, Irigaray processes that language which represents the feminine will build a symbolic "home" for women. This will bring the possibility of women becoming subjects, and create a place or position for women in culture. As Irigaray emphasizes,

"It is important to understand and modify the instruments of society and culture that regulate subjective and objective rights. Social justice, and especially sexual justice, cannot be achieved without changing the law of language and conceptions of truths and values structuring the social order. Changing the instruments of culture is just as important in the medium to long term as a redistribution of goods in the strict sense. You can't have one without the other." (1993:22)[40]

For a long time, Irigaray has been criticized as essentialist. These criticisms are largely the misreading of her references to the female body as a means to articulate women's specificity. Her symbolizations of the female body constitute a philosophical critique of rationality which has excluded the body. She employs Nietzsche's oeuvre for the inclusion of the body at philosophical level the body, not as essential, but as a cultural production. Irigaray's referencing to bodies is always morphological, 
symbolic representations of the body which are confined to the maternal, but which symbolize the importance of language and new forms of practice, which is significant for women to become subjects. She has tactically articulated the symbol of the two lips for women - one representing the site of female genealogy, the possibility of representing the mother-daughter relationship, and the other, the site of language of the feminine, parler femme. With this symbol she seeks to criticize sexual identity premised on male sexual significance and its appropriations in the Symbolic.

Irigaray's notion of divinity for women is an example of mimetic strategy for constituting women-as-subjects. Male subjectivity is guaranteed by the Father-God who creates by the Holy Word. A differently conceptualized notion of the divine will be necessary for female subjectivity. For women, the mother-daughter relationship is divine, as is the mission of creating subjectivity of the female. A notion of the divine for women provides an ideal, a necessary "third term" that functions against the dangerous fusion of the mother-daughter relationship to prevent autonomy.

Major texts of Irigaray are devoted to the possibilities of "women-becoming-subjects", and to "an ethics of sexual difference". Emmanuel Lévinas's conceiving of "ethical subjectivity as the time for the Other" as well as his ideas of ethics of the face-to-face relation premised on absolute alterity provide her with the means to theorize sexual difference and to propose language of ethical exchange. The relationship between the sexes in an economy of sexual difference will have to be mediated, not by the distancing and repressive violence of opposition, but by processes that engage both the possibility of relationship and the incommensurability between the two genders. Irigaray describes patriarchy as "an exclusive respect for the genealogy of sons and fathers and the competition between brothers" (Whitford, 1990:174)[41]. Symbolization of the genealogies of women and representation of the mother-daughter relationship are further conditions for identity that is linked to the ability to speak as women, the language of women.

Irigaray interrogates the objectives of women's social movement and problematizes feminist aspirations to equality. In her consideration, the desire to be the same as men does nothing to shift the binary structure of dominating, destructive power, nor to engage desires of the feminine. The achievement of equality may bring certain necessary and unstable gains, but they will mean that women are implicated in the reproduction of existing system dominated by men, in its explicit or implicit manner. Sexual difference will constitute a "fecund relation between the sexes", and is the condition for ongoing cultural progression.

As demonstrated in a male-dominated society, a woman's development, however radical it may seek to be, would thus not suffice to liberate woman as a single class.
And to date no political theory or political practice has resolved, or sufficiently taken the class of women into consideration, even though neo-Marxism has a more fair treatment of the issue. Admittedly, in any societies, women do not take up a single class, and their dispersion among several classes makes their political struggle complex, their demands sometimes contradictory. Irigaray's feminist theories foregrounding essential discursive difference are more practical in this regard.

Theoretical claims of Irigaray are further related to such feminine models as "placental economy", "mucosity", "fluidity", etc. For her, the supernatural entities also functions as necessary mediators. In ethical exchanges across sexual difference each might be other for the other, a constant and dynamic distribution of otherness in contrast to otherness as fixed to the female. The useful employment of metaphors of fluidity can thus be able to signify the mobility that is necessary to the reconstructing of relations between the two genders. In view of this, it can be concluded that Irigaray not only shares a deconstructionist view with other French feminists in that there is no subject beyond the fixed categories of gender but also processes a theoretical space for women to mediate and formulate their subjective identity.

Irigaray's feminist philosophies can be illustrative and applicable in that "a separatist space" can be formulated by various means and strategies. As a matter of fact, there have first been emerging in philosophical, cultural and literary field female pioneering theorists and writers. They have in their special domains advanced theories and discourses of their own at a metaphysical level. Strongly feminist stylistic contents rather than the "ungendering of writings" are perhaps the unique label of them. Generations of feminist writers such as de Beauvoir and Irigaray, have set up an example followed by younger writers in their academic and cultural works, which are now still influential in the global context. Mainstream publishers have continuously been turning out works by female authors in fiction, drama, poetry, prose, translations, critical theory, etc. in large quantities with a clear sensibility to the nuances of femininity. Typical cases are not of scarcity even in China, such as Li Yinhe, Zhai Yongming, Wei Hui and others.

One can find further instances of Irigaray's theoretical directions outside academic field but in social life. Many are at handy, such as the participation of women in the military as a full civil identity. The relationship between feminism and the military and more generally between gender and violence is clearly a contemporary concern of great importance. Armed forces have consisted primarily of males and females in different roles, notwithstanding the Amazon legends. Owing to the feminist discoursive power, the opening up of the armed forces to women as an issue of human rights is so noteworthy. The women's peace encampments is also relevant to global feminism, with those at Greenham Common and Molesworth in England, 
Comiso in Italy, Hunstruck in former West Germany, Seneca and Puget Sound in the United States, and so forth. These are echoing to Virginia Woolf's word, “As a woman I have no country...my country is the whole world", almost a maintained idea of Irigaray too.

The ultimate spirit of Irigaray's feminist philosophies is actually not confined in the divided autonomy of females and males, but related to some common theme and greater paradigm: the "oneness" of life, people and Earth. The creation of common world awareness has given rise to what she describes as an "upsurge" of religious universalism, concerning gods for females, fire, air, great earth, female language and even their holidays. The narrative argument on the above can frequently found in her key writings. One may reflect upon the Gaia hypothesis while digesting Irigaray's viewpoints on human-nature relationship, or the rubric of "Justice, Peace and the Integrity of Creation". This is not inconsistent with classical Chinese philosophy of harmony allowing differences. The name "Gaia" means Goddess of our Earth, but the principle that, for instance, the atmosphere is a system of equilibrium involving movement of gaseous content and changes of temperature, is clearly related to almost all elements of environmentalism. Theoretically, it is proper to remark that Irigaray has endeavored to promote the integrity of creation in terms of "eco-spirituality", "eco-justice" combined.

So many feminist practitioners and students have valued Irigaray's feminist theory consciously, because she has never lacked a sensibility to the needs and demands in not only academic field but also in public life. Her scholarship has covered some important studies related to the core. Many of her arguments have undoubtedly expanded to other aspects of social life. The questions and challenges presented in her works remain relevant. For many feminist practitioners and cultural theorists, especially in the PRC, she remains a model of radical, principled, functional feminism.

\section{About the Author}

Zhang Pinggong, Ph.D (Staffs. U.K.), currently works at Guangdong University of Foreign Studies in China as Professor of English Literature and Cultural Studies within the Faculty of English Language and Culture, and Researcher at the Center for Foreign Literary and Cultural Studies of GDUFS.

This essay was first delivered at the Conference on the Western Left Wing Literary Theory and Theory of Space held in Fudan University on April 13, 2018, in Shanghai.

\section{REFERENCES}

[1] Brooks, Ann. Postfeminism: Feminism, Cultural Theory and
Cultural Forms (1997). London: Routledge.

[2] Eagleton, Terry. Literary Theory - An Introduction (1997). $2^{\text {nd }}$ Edition. Oxford: Blackwell Publishers.

[3] Storey, John. An Introduction to Cultural Theory and Popular Culture (1997), $2^{\text {nd }}$ Edition. Hertfordshire: Prentice Hall / Harvester Wheatsheaf.

[4] Irigaray, Luce. This Sex Which Is Not One Translated by Claudia Reeder, in New Feminisms, ed. Elaine Marks and Isabelle de Courtivron (1981). New York: Cornell University Press.

[5] Irigaray, Luce. This Sex Which Is Not One, Translated by Claudia Reeder, in New Feminisms, ed. Elaine Marks and Isabelle de Courtivron (1981). New York: Cornell University Press.

[6] Barry, Peter. Beginning Theory - An Introduction to Literary and Cultural Theory (1995). Manchester: Manchester University Press.

[7] Humm, Maggie. The Dictionary of Feminist Theory (1995). $2^{\text {nd }}$ Edition. Hertfordshire: Prentice Hall / Harvester Wheatsheaf.

[8] Irigaray, Luce. This Sex Which Is Not One, Translated by Claudia Reeder, in New Feminisms, ed. Elaine Marks and Isabelle de Courtivron (1981). New York: Cornell University Press.

[9] Eagleton, Terry. Literary Theory - An Introduction (1997). $2^{\text {nd }}$ Edition. Oxford: Blackwell Publishers.

[10] Burke, Carolyn. 'Translation Modified: Irigaray in English', Engaging with Irigaray (1994). ed. Carolyn Burke et al. New York: Columbia University Press.

[11] Whitfofd, Margaret. "Rereading Irigaray", Between Feminism and Psychoanalysis (1990). (ed.) Teresa Brennan. London: Routledge.

[12] Barry, Peter. Beginning Theory - An Introduction to Literary and Cultural Theory (1995). Manchester: Manchester University Press.

[13] Hu, Quansheng. "A Comparative Study on American and French Feminist Criticism”, Journal of Foreign Literature (1997, No. 1). Nanjing: Nanjing University Press.

[14] Silverman, Hugh J. Cultural Semiosis-Tracing the Signifier, Continental Philosophy VI (1998) (ed.), London: Routledge.

[15] Whitfofd, Margaret. "Rereading Irigaray", Between Feminism and Psychoanalysis (1990). (ed.) Teresa Brennan. London: Routledge.

[16] Zhang, Yanbing. "Criticism on the Theory of Language in French Feminism". Journal of Fudan University (Social Sciences Edition) (1998, No. 2). Shanghai: Fudan University Press.

[17] Zhang, Pinggong. "Interpreting the Major Themes of Irigaray's Postmodern Feminist Theory", Theoretical Development Trends towards the End of the $20^{\text {th }}$ Century, (2001) (eds.) Yang Dingchuan and Hu Chonghan, Changsha: Hunan People's Press.

[18] Irigaray, Luce. Thinking the Difference for a Peaceful Revolution, Translated by Karin Montin (1994), London: 
The Athlone Press.

[19] Zhang, Pinggong. "Interpreting the Major Themes of Irigaray's Postmodern Feminist Theory", Theoretical Development Trends Towards the End of the $20^{\text {th }}$ Century, (2001) (eds.)

[20] Braidotti, Rosi. 'Of Bugs and Women: Irigaray and Deleuze on the Becoming-Woman', Engaging with Irigaray (1994), ed. Carolyn Burke et al. New York: Columbia University Press.

[21] Humm, Maggie. The Dictionary of Feminist Theory (1995). $2^{\text {nd }}$ Edition. Hertfordshire: Prentice Hall / Harvester Wheatsheaf.

[22] Braidotti, Rosi. 'Of Bugs and Women: Irigaray and Deleuze on the Becoming-Woman', Engaging with Irigaray (1994), ed. Carolyn Burke et al. New York: Columbia University Press.

[23] Martin, Alison. "Luce Irigaray and Divine Matter"”, Women and Representation (1995). (ed.) Diana Knight and Judith Still. Nottingham: WIF Publishers.

[24] Irigaray, Luce. This Sex Which Is Not One Translated by Claudia Reeder, in New Feminisms, ed. Elaine Marks and Isabelle de Courtivron (1981). New York: Cornell University Press.

[25] Martin, Alison. "Luce Irigaray and Divine Matter", Women and Representation (1995). (ed.) Diana Knight and Judith Still. Nottingham: WIF Publishers.

[26] Irigaray, Luce. This Sex Which Is Not One, Translated by Claudia Reeder, in New Feminisms, ed. Elaine Marks and Isabelle de Courtivron (1981). New York: Cornell University Press.

[27] Qin, Xiubei. "A Historical Study on the Gender Differences in the English Language", Journal of Modern Foreign Languages (1996, No. 2). Guangzhou: Guang Foreign Language Education Press.

[28] Irigaray, Luce. "The 'Mechanics' of Fluids" in Speculum of the Other Women, Translated by Gillian C. Gill, (1985). New York: Cornell University Press.
[29] Martin, Alison. "Luce Irigaray and Divine Matter"”, Women and Representation (1995). (ed.) Diana Knight and Judith Still. Nottingham: WIF Publishers.

[30] Muraro, Luisa. "Female Genealogies", Engaging with Irigaray (1994). Ed. Carolyn Burke et al. New York: Columbia University Press.

[31] Irigaray, Luce. An Ethics of Sexual Difference, Translated by Carolyn Burke and Gillian C. Gill (1993), London: The Athlone Press.

[32] Martin, Alison. “Luce Irigaray and Divine Matter'”, Women and Representation (1995). (ed.) Diana Knight and Judith Still. Nottingham: WIF Publishers.

[33] Irigaray, Luce. This Sex Which Is Not One, Translated by Claudia Reeder, in New Feminisms, ed. Elaine Marks and Isabelle de Courtivron (1981). New York: Cornell University Press.

[34] Irigaray, Luce. This Sex Which Is Not One, Translated by Claudia Reeder, in New Feminisms, ed. Elaine Marks and Isabelle de Courtivron (1981). New York: Cornell University Press.

[35] Whitfofd, Margaret. "Rereading Irigaray", Between Feminism and Psychoanalysis (1991). (ed.) Teresa Brennan. London: Routledge.

[36] Spybey, Tony. Globalization and World Society (1996), Cambridge: Polity Press.

[37] Brooks, Ann. Postfeminism: Feminism, Cultural Theory and Cultural Forms (1997). London: Routledge.

[38] Whitford, Margaret. "Irigaray, Utopia, and the Death Drive", Engaged with Irigaray (1994). (ed.) Carolyn Burke et al. New York: Columbia University Press.

[39] Irigaray, Luce. An Ethics of Sexual Difference, Translated by Carolyn Burke and Gillian C. Gill (1993), London: The Athlone Press.

[40] Irigaray, Luce. Je, tu, nous-Toward a Culture of Difference, Translated by Alison Martin (1993), London: Routledge.

[41] Whitfofd, Margaret. "Rereading Irigaray", Between Feminism and Psychoanalysis (1991). (ed.) Teresa Brennan. London: Routledge. 